\title{
Biomass production and distribution in seedlings of Coffea arabica genotypes under contrasting nursery environments in southwestern Ethiopia
}

Taye Kufa

Ethiopian Institute of Agricultural Research, Jimma Research Center, Jimma, Ethiopia; kufataye@yahoo.com

Received 18 June 2012; revised 28 July 2012; accepted 8 August 2012

\begin{abstract}
In Ethiopia, the natural forests with the occurrence of wild Arabica coffee gene pools are under constant threats, largely due to anthropogenic activities. The study was conducted to compare the variability among the wild arabica coffee genotypes in biomass assimilation and allocation patterns under varying light and irrigation conditions at the Jimma Research Center, southwest Ethiopia. The treatments included irradiance (moderate and full sunlight), irrigation (well watered and water stressed) regimes and twelve coffee genotypes of different geographical areas. One-year-old seedlings were used to impose the environmental stresses and to re-

dry matter share varied for the seedling growth parts $($ root $=22 \%$, leaf $=35 \%$, stem $=43 \%$ and whole shoot $=78 \%$ ). The root growth followed the order of Harenna > Yayu > Bonga > BerhaneKontir populations, which were grouped into three broad cluster classes. The reverse was true for the leaf and whole-shoot partitioning, demonstrating the interplay between above- and below-ground growth parts partly due to genotype, environment and/or their interactions. As a whole, the study demonstrates the need to consider both dry matter assimilation and partitioning patterns in identifying desirable genotypes and optimum environments for future breeding program in Ethiopia.
\end{abstract} cord dry mass of leaves, main stem, primary branches and root growth. Each organ was separetly oven-dried and total dry matter production and allocation patterns were measured and analyzed. The results depicted highly significant differences between the contrasting irradiance and irrigation regimes as well as among coffee genotypes for most of the parameters considered. Accordingly, root, leaf, stem, whole-shoot and total biomass assimilation and root partitioning were higher for unshaded, water stressed and Harenna genotypes from the respective treatment groups. Significantly the lowest and highest root and shoot biomass values were recorded for Berhane-Kontir and Harenna genotypes, respectively. Likewise, coffee seedlings significantly differed in root dry mass and root to shoot ratio, dry matter partitioning due to the main and combined treatment effects. Most accessions had relatively lower assimilations in shade as compared to full sun light conditions. Conversely, leaf share was significantly high under moderate shade environments and for irrigated and Berkane-Kontir genotypes. The total
Keywords: Ecological Physiology; Environment; Genetic Diversity; Seedling Growth Response; Wild Ethiopian Coffee Population

\section{INTRODUCTION}

The montane rainforest areas in Ethiopia are the only known center of origin and genetic diversity for the highland arabica coffee (Coffea arabica L.). In its original natural habitats, arabica coffee occurs in the multistrata of forest ecosystems and thus it is a shade-adapted plant. Its response to light has caused it to be traditionally considered a heliophobic plant requiring high, somewhat dense cover in a plantation. Today, the cultivation of coffee in open sun is not uncommon in most coffee producing countries, though its sustainability is questionable. It is known that coffee trees with high productivity potential are capable of high yields when they are cultivated intensively without shade [1,2].

Although arabica coffee is said to be a shade-loving plant with greater quantum utilization efficiency for photosynthesis, excessive shading or light interception by the upper two to three canopy strata of various tree species would decrease growth and productivity of the 
crop, as the plant spends much of its photosynthetic activities for maintenance. On the other side, if the light intensity is too high, there will be inadequate reaction centers in the leaves of the crop to accommodate the light energy and convert it into biochemical energy. As a result, the coffee trees excessively photo-respires and eventually most of the stored carbohydrates become depleted. Consequently, the trees may suffer from a serious dieback mostly due to excessive fruit load via enhanced flowering in full sunlight compared to shade conditions and coffee production limitations and coffee shade interactions [3,4]. Besides, excessive evapo-transpiration and severe drought stress, death of actively growing shoot parts, seasonal crinkling of leaves, frost damage and subsequent yield reduction are common problems observed in unshaded coffee orchards [5].

It is known that photosynthesis in coffee follows the $\mathrm{C}_{3}$ or Calvin cycle pathway, as coffee plants placed in darkness after a period of light produce a burst of $\mathrm{CO}_{2}$ following photorespiration [6]. Work done in Kenya [7] revealed that about $95 \%$ of the biomass of a plant are derived from the carbohydrates manufactured in the green parts by the process of photosynthesis and the remaining 5\% come from mineral elements absorbed by the roots. Large regular yields of coffee can be obtained only when both the carbohydrates and mineral element supplies within the tree are adequate to meet the needs of the developing fruits and the shoots and roots which will support the following year's crop. The capacity of the plant to produce carbohydrate depends mainly on the total green (mainly leaf) area engaged in photosynthesis and the net photosynthetic rate per unit green surface area [7]. The same author showed that dry matter production in any crop depends upon leaf area index, structure of the canopy, photosynthetic rate per unit of leaf area and strength of the metabolic sinks in attracting assimilates.

The physiological mechanisms involved in the adaptation of the juvenile trees to light have remained less investigated in the diverse coffee germplasm collections at the center of origin and genetic diversity. Shade plants essentially follow strategies of optimum use and conservation of available energy. The need to know how the coffee plant accumulates and partitions dry matter to the various plant organs under a given management cannot be overemphasized. Moreover, this information is necessary as a selection criterion for coffee cultivars as well as for determining optimum management levels [6,7]. This aspect, however, has not yet deserved attentions in the evaluation of the immense arabica coffee genetic resources growing under wide ecologies.

The growth and seed production of a plant is a result of the integrated processes of photosynthetic carbon dioxide assimilation and subsequent partitioning and utili- zation of the assimilated carbon. This requires efficient translocation of photo-assimilates to the developing plant parts $[8,9]$. However, there is little information on the phenotypic plasticity and biomass partitioning of coffee trees under varying light gradients in heterogeneous field conditions. To this effect, understanding the influence of environmental stress pressures such as direct solar radiation on growth and physiology of coffee plant is important to examine the coping mechanisms involved in the shade-adapted Arabica coffees. The natural coffee forests with the occurrence of maximum plant diversity includeing the wild coffee genetic resources are under continuous threats of erosion due to several factors and needs urgent conservation measures [10]. According to [11], nowadays, it is not uncommon to see coffee tree drying symptoms due to climate changes that have resulted in physiological disorders between vegetative and reproductive growths. This is associated with continuous flowering and heavy crop loads as a result of changes in weather patterns with erratic rainfalls. The situation is aggravated by the outbreak of insect pests and diseases, requiring new corrective strategies to revive Arabica gene pools from possible fast and irreversible losses. Hence, this study would provide baseline research information on the use of growth traits in the selection of coffee genotypes in breeding program for sustainable management and conservation of coffee genetic diversity and its healthy environments. Therefore, this ex-situ experiment was carried out to compare the variability in biomass prodution and allocation patterns in seedlings of arabica coffee germplasm accessions under varying nursery irradiance and irrigation conditions at Jimma Research Center in southwest Ethiopia.

\section{MATERIALS AND METHODS}

\subsection{The Study Site}

The experiment was conducted at a common nursery garden of the Jimma Research Center, southwest Ethiopia $\left(7^{\circ} 46^{\prime} \mathrm{N}, 36^{\circ} 0^{\prime} \mathrm{E}, 1750 \mathrm{~m} . \mathrm{a} . \mathrm{s} . \mathrm{l}\right)$. This is a national coffee research coordinating center were about 5960 live coffee germplasm are found in field gene banks for research work. The area receives adequate amount of rainfall with an average rainfall of 1595 mm per annum distributed into 173 days. The driest season lasts between December and January. The average maximum and minimum air temperatures are $25.9^{\circ} \mathrm{C}$ and $11.2^{\circ} \mathrm{C}$, respectively, the coldest month being December [12].

\subsection{Experimental Treatments and Design}

Ripe red coffee cherries were collected in 2004/2005 from four wild coffee populations in the montane rainforests of southeastern and southwest Ethiopia. The 
recommended ideal potting medium [13] was prepared from topsoil and decomposed coffee husk at the respecttive proportion of $3: 1(\mathrm{v} / \mathrm{v})$ and firmly filled in black plastic pots (volume $=5.8 \mathrm{~L}$ ) perforated at the bottom. The plant plastic pots were arranged on nursery seedbed and the prepared coffee seeds were sown in each pot. The recommended post-sowing nursery operations were applied [14] and the seedlings were uniformly managed under partial shade conditions and irrigated at every four-day intervals.

After one-year of ex situ establishment under common garden, the shade treatment was applied for three consecutive dry months between March and May. In this case, seedlings were divided into equal halves to impose the contrasting shade and irrigation treatments. The studied environmental modification treatments included shading levels (moderate shading and full solar light interception), two irrigation treatments (well-watered and water deficit) and twelve coffee germplasm genotypes of different geographical origins in Ethiopia. The central five coffee seedlings were used to record destructive growth parameters for each treatment. These include dry weight of leaves, main stem, primary branches and root system. The roots were immersed and washed in clean water to remove adhering soil. Subsequently, each plant part was separately oven-dried at $105^{\circ} \mathrm{C}$ for $24 \mathrm{~h}$ and weighed using a sensitive balance. Finally, total dry matter production and allocation patterns were determined in seedlings of arabica coffee germplasm accessions under contrasting nursery microclimatic varables (Table 1) monitored and described [12].

\subsection{Data Analysis}

The statistical analysis was accomplished using SAS

Table 1. Microclimate variables in the studied full sunlight and moderately shaded coffee nursery site at Jimma Research Center.

\begin{tabular}{cccc}
\hline \multirow{2}{*}{ Variable } & \multirow{2}{*}{ RH (\%) } & \multicolumn{2}{c}{ Temperature $\left({ }^{\circ} \mathbf{C}\right)$} \\
\cline { 3 - 4 } & & Air & Soil \\
\hline Time of day & $*$ & $* *$ & Ns \\
Night & $80.97 \pm 9.97 \mathrm{a}$ & $16.56 \pm 1.74 \mathrm{~b}$ & $19.10 \pm 7.16$ \\
Day & $70.82 \pm 6.03 \mathrm{~b}$ & $20.47 \pm 2.01 \mathrm{a}$ & $23.83 \pm 4.23$ \\
Shading level & Ns & Ns & Ns \\
Full sun & $73.42 \pm 8.57$ & $18.75 \pm 3.17$ & $24.03 \pm 5.95$ \\
Shaded & $78.36 \pm 9.52$ & $18.28 \pm 2.46$ & $18.90 \pm 5.60$ \\
Mean & 75.89 & 18.51 & 21.46 \\
CV (\%) & 3.17 & 3.58 & 30.42 \\
Time ${ }^{*}$ shade & Ns & Ns & Ns \\
\hline
\end{tabular}

Ns $=$ Not significant; ${ }^{*} \mathrm{P}<0.05 ;{ }^{* *} \mathrm{P}<0.001$. Means with the same letter is not different from each other according to Tukey test at $\mathrm{P}=0.05$. for Windows version 8.1 (SAS Institute Inc., Cary, NC). Two-way analysis of variance (ANOVA) was computed for each growth variable considered in a factorial experiment arranged in a randomized complete block design with three replications. Principal component analysis was computed to compare the variability among the coffee germplasm accessions. Moreover, treatment means were ranked according to Tukey test at $\mathrm{P}=0.05$, whenever the F-test showed significant differences. Figures of significant interactions were made with the Sigma Plot SPW9.0 (SYSTAT Software, Inc.).

\section{RESULTS}

\subsection{Biomass Production}

\subsubsection{Shoot Biomass}

Significantly $(\mathrm{P}<0.001)$ higher stem (main stem and branch) biomass (17.48 $\pm 2.49 \mathrm{~g})$ was obtained from unshaded plots than from those in partial shade environments. In addition, insignificantly higher leaf dry weight (13.58 g) was found for sun-exposed seedlings (Table 2). Similarly, most shoot growth parameters were significantly higher for water deficit subjected seedlings. Hence, significantly $(\mathrm{P}<0.05)$ higher leaf dry mass and main stem plus branch $(\mathrm{P}<0.05)$ were obtained for non-irrigated than for well-watered seedlings. With regard to shade or irrigation, stem biomass was higher (17.48 g) in the open sun than the shade $(15.60 \mathrm{~g})$ with about $11 \%$ difference. Coffee accessions significantly $(\mathrm{P}<0.05)$ differed in stem dry weight, with average results ranging from $14.36 \pm 1.85$ to $19.08 \pm 2.01 \mathrm{~g}$ for Berhane-Kontir (III-2) and Harenna (I-1) seedlings, respectively (Table 2). Most accessions had relatively lower growth responses in shade conditions as compared to the sun plots. As a result, higher dry mass of leaf, root and total dry matter were recorded for seedlings exposed to direct sunlight (Figure 1). The results depict significant differences among accessions in root dry mass and root to shoot ratio; the values followed the descending order of Harenna $>$ Yayu $>$ Bonga $>$ Berhane-Kontir accessions.

\subsubsection{Root Biomass}

A significantly $(\mathrm{P}<0.01)$ higher root dry weight $(8.93$ g) was obtained from unshaded than from partially shaded seedlings (7.89 g), where a reduction of about $12 \%$ was noted. The difference between watering regimes was also significant $(\mathrm{P}<0.01)$ for root dry mass and was higher for drought-stressed (8.90 g) than for well-irrigated (7.92 g) seedlings. In the same manner, coffee accessions significantly differed $(\mathrm{P}<0.01)$ in root dry mass. Consequently, the lowest (III-1 = $6.48 \mathrm{~g}$ ) and highest $(\mathrm{I}-2=10.43 \mathrm{~g})$ average values were obtained from Berhane-Kontir and Harenna seedlings, respec- 
Table 2. Shoot and root growth (means \pm S.D) of seedlings of arabica coffee genotypes under varying irradiance and irrigation regimes.

\begin{tabular}{|c|c|c|c|c|c|}
\hline Treatment & LDW (g) & SDW (g) & RDW (g) & $\mathbf{R}: \mathbf{S}$ & TDM (g) \\
\hline Irradiance & Ns & $* *$ & $* *$ & Ns & $* *$ \\
\hline Open sun & $13.58 \pm 1.59$ & $17.48 \pm 2.49 a$ & $8.93 \pm 1.64 a$ & $0.29 \pm 0.03$ & $39.99 \pm 5.31 \mathrm{a}$ \\
\hline Moderate shade & $13.06 \pm 0.91$ & $15.60 \pm 1.55 b$ & $7.89 \pm 1.52 b$ & $0.28 \pm 0.04$ & $36.54 \pm 3.13 b$ \\
\hline Irrigation & $*$ & $*$ & $* *$ & Ns & ** \\
\hline Water stressed & $13.68 \pm 1.40 \mathrm{a}$ & $17.14 \pm 2.53 a$ & $8.90 \pm 1.52 a$ & $0.29 \pm 0.03$ & $39.72 \pm 4.95 \mathrm{a}$ \\
\hline Well-watered & $12.95 \pm 1.12 b$ & $15.94 \pm 1.81 b$ & $7.92 \pm 1.66 \mathrm{~b}$ & $0.27 \pm 0.04$ & $36.81 \pm 3.92 b$ \\
\hline Genotype & Ns & $*$ & $* *$ & ** & $*$ \\
\hline $\mathrm{I}-1$ & $13.25 \pm 0.80$ & $19.08 \pm 2.01 \mathrm{a}$ & $10.02 \pm 1.11 \mathrm{a}$ & $0.31 \pm 0.04 \mathrm{ab}$ & $42.34 \pm 3.43 a$ \\
\hline $\mathrm{I}-2$ & $13.06 \pm 0.89$ & $18.47 \pm 2.09 \mathrm{ab}$ & $10.43 \pm 1.23 a$ & $0.33 \pm 0.01 \mathrm{a}$ & $41.95 \pm 4.03 \mathrm{ab}$ \\
\hline $\mathrm{I}-3$ & $13.73 \pm 1.85$ & $16.63 \pm 1.78 a b$ & $9.22 \pm 0.95 \mathrm{ab}$ & $0.31 \pm 0.02 \mathrm{ab}$ & $39.57 \pm 4.52 \mathrm{ab}$ \\
\hline II-1 & $13.63 \pm 1.78$ & $16.65 \pm 2.47 \mathrm{ab}$ & $8.30 \pm 1.44 \mathrm{abc}$ & $0.28 \pm 0.02 \mathrm{abc}$ & $38.58 \pm 5.57 \mathrm{ab}$ \\
\hline II-2 & $12.34 \pm 0.66$ & $15.52 \pm 1.33 \mathrm{ab}$ & $7.97 \pm 1.11 \mathrm{abc}$ & $0.28 \pm 0.03 \mathrm{abc}$ & $35.82 \pm 2.90 \mathrm{ab}$ \\
\hline II-3 & $12.81 \pm 0.68$ & $15.29 \pm 1.66 \mathrm{ab}$ & $8.15 \pm 1.34 \mathrm{abc}$ & $0.29 \pm 0.04 \mathrm{abc}$ & $36.24 \pm 2.84 \mathrm{ab}$ \\
\hline III-1 & $11.91 \pm 0.51$ & $14.84 \pm 1.45 \mathrm{ab}$ & $6.48 \pm 1.09 c$ & $0.25 \pm 0.04 \mathrm{bc}$ & $33.23 \pm 1.93 \mathrm{~b}$ \\
\hline III-2 & $12.97 \pm 1.29$ & $14.36 \pm 1.85 b$ & $7.22 \pm 1.66 \mathrm{bc}$ & $0.27 \pm 0.04 \mathrm{abc}$ & $34.54 \pm 4.21 \mathrm{ab}$ \\
\hline III-3 & $14.37 \pm 1.45$ & $16.11 \pm 2.41 \mathrm{ab}$ & $6.86 \pm 1.20 \mathrm{bc}$ & $0.23 \pm 0.03 \quad$ c & $37.33 \pm 4.65 \mathrm{ab}$ \\
\hline IV-1 & $13.87 \pm 0.76$ & $17.16 \pm 1.50 \mathrm{ab}$ & $8.67 \pm 0.30 \mathrm{abc}$ & $0.28 \pm 0.02 \mathrm{abc}$ & $39.69 \pm 2.09 a b$ \\
\hline IV-2 & $14.41 \pm 0.67$ & $18.06 \pm 1.24 \mathrm{ab}$ & $9.39 \pm 1.00 \mathrm{ab}$ & $0.29 \pm 0.01 \mathrm{abc}$ & $41.87 \pm 2.81 \mathrm{ab}$ \\
\hline IV-3 & $13.52 \pm 2.12$ & $16.29 \pm 3.37 \mathrm{ab}$ & $8.23 \pm 2.43 \mathrm{abc}$ & $0.27 \pm 0.05 \mathrm{abc}$ & $38.03 \pm 7.63 \mathrm{ab}$ \\
\hline Mean & 13.32 & 16.54 & 8.41 & 0.28 & 38.26 \\
\hline CV (\%) & 7.95 & 9.35 & 10.72 & 9.31 & 8.20 \\
\hline
\end{tabular}

Ns $=$ Not significant; ${ }^{* * *}$ and ${ }^{* * *}=$ significant at $\mathrm{P}<0.05, \mathrm{P}<0.01$ and $\mathrm{P}<0.001$, respectively. Means followed by same letter with in a column are not different from each other (Tukey test at $\mathrm{P}=0.05$ ). Abbreviations: $\mathrm{LDW}=$ leaf dry weight, $\mathrm{SDW}=$ stem dry weight, $\mathrm{RDW}=$ root dry weight, $\mathrm{R}: \mathrm{S}=$ root to shoot ratio, $\mathrm{TDM}=$ total dry matter.

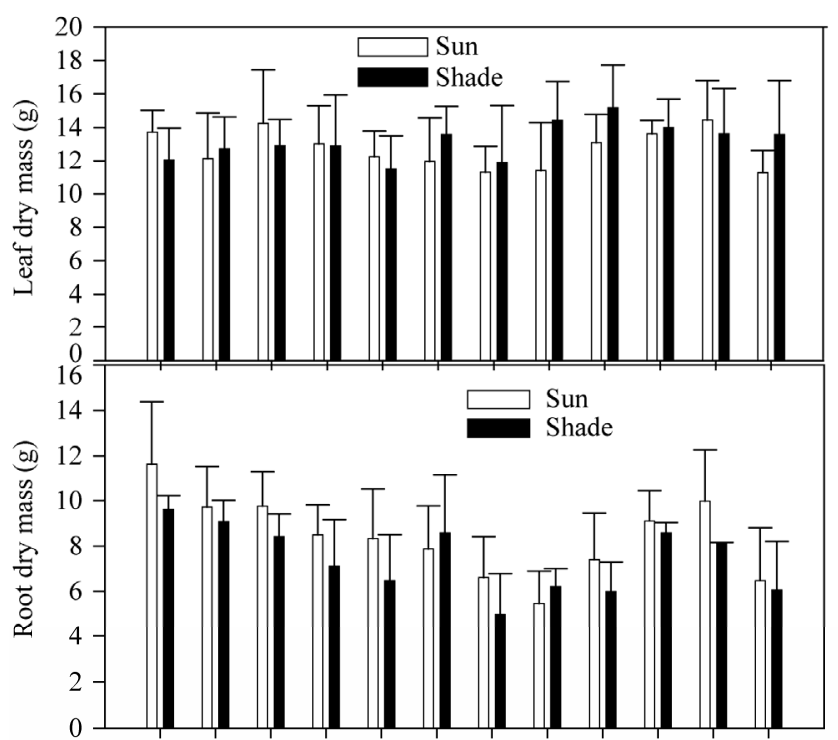

I-1 I-2 I-3 II-1 II-2 II-3 III-1 III-2 III-3 IV-1 IV-2 IV-3

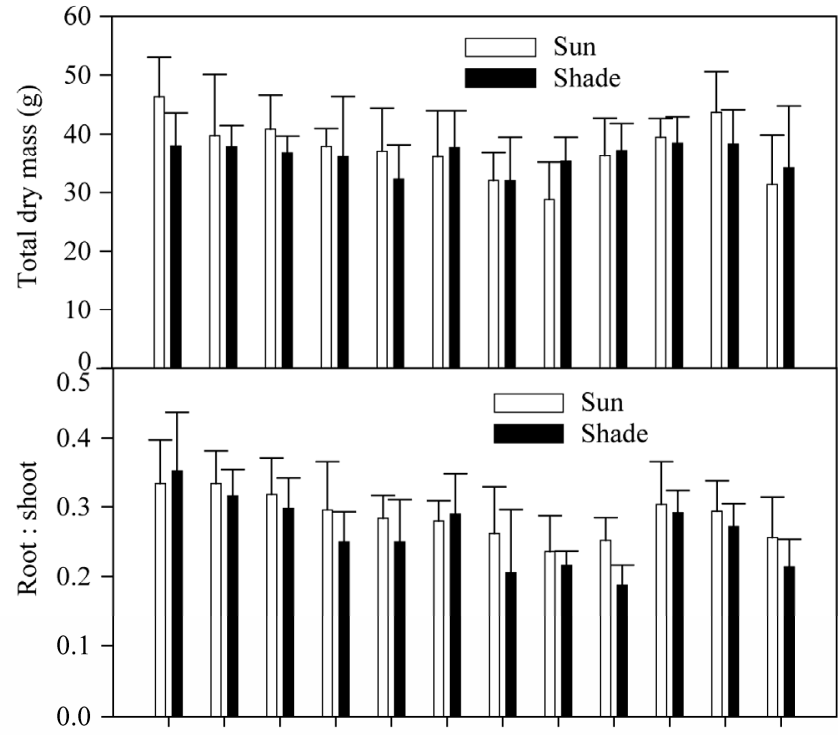

I-1 I-2 I-3 II-1 II-2 II-3 III-1 III-2 III-3 IV-1 IV-2 IV-3

Figure 1. Biomass yield and root to shoot ratio of coffee accessions under full sunlight and shaded conditions. 
tively (Table 2). In general, the Harenna seedlings had a higher root mass than the others, particularly the Berhane-Kontir accessions, which had a low root biomass ranging between 6.48 and $7.22 \mathrm{~g}$. This was less than the overall average root dry mass of $8.41 \mathrm{~g}$. The ratios of root to shoot dry mass of the seedlings also significantly differed among the coffee accessions, but not between irradiance and irrigation levels. The absence of significant differences due to shade and irrigation suggests that the duration of the treatments was too short to considerably change root biomass accumulation. However, root to shoot ratio of some seedlings surpassed those in shadow conditions. The significantly lowest (III-3 $=0.23$ ) and highest ( $\mathrm{I}-2=0.33$ ) root to shoot values were determined for the Berhane-Kontir and Harenna accessions, respectively. The root to shoot ratio result was higher for the Harenna as compared with those from Berhane-Kontir coffee germplasm (Figure 2).

\subsubsection{Total Biomass}

The analysis of variance comparing the total dry matter production of coffee seedlings depicts significant $(\mathrm{P}<$ 0.01 ) differences between the two shade and irrigation treatments as well as due to accessions $(\mathrm{P}<0.05)$. Significantly ( $\mathrm{P}<0.001)$ higher total dry matter yield (39.99 $\pm 5.31 \mathrm{~g}$ ) was obtained from the full sun light than from the shaded plots. There was about $9 \%$ reducetion in total dry matter production of seedlings in moderately shaded seedlings as compared to those in open sunlight. Similarly, significantly $(\mathrm{P}<0.01)$ higher total dry matter was obtained from drought-stressed than well-watered seedlings. The results also reveal significantly lowest (III-1 = $33.23 \mathrm{~g})$ and highest ( $\mathrm{I}-1=42.34 \mathrm{~g})$ total biomass from the Berhane-Kontir and Harenna coffee accessions, respectively (Table 2, Figure 2). Accessions from Harenna (I-2 = $41.95 \mathrm{~g}$ ) and Berhane-Kontir (III-2 = $34.54 \mathrm{~g}$ ) had the next maximum and low average values, respectively, though no significance was detected among the other accessions. The results of the destructive parameters manifested that the coffee germplasm accessions were grouped into three broad classes. The first group consisted of a mixture of accessions from Yayu (IV-1 and IV-2), Bonga (II-1), Berhane-Kontir (III-3) and Harenna (I-3). Whereas, the Bonga and Harenna populations were classified into the second and the third group (Figure 3 ).

\subsection{Biomass Partitioning}

The amount of total dry mass partitioned to the root part was comparable between shade treatments, though it was higher in full sun irradiance $(22.22 \% \pm 1.89 \%)$ and drought stressed $(22.35 \% \pm 2.02 \%)$ seedlings. In contrast, leaf partitioning was significantly different according to the level of shade $(\mathrm{P}<0.001)$ and irrigation $(\mathrm{P}<0.05)$. As a result, the mean values ranged from $34.11 \% \pm 2.19 \%$

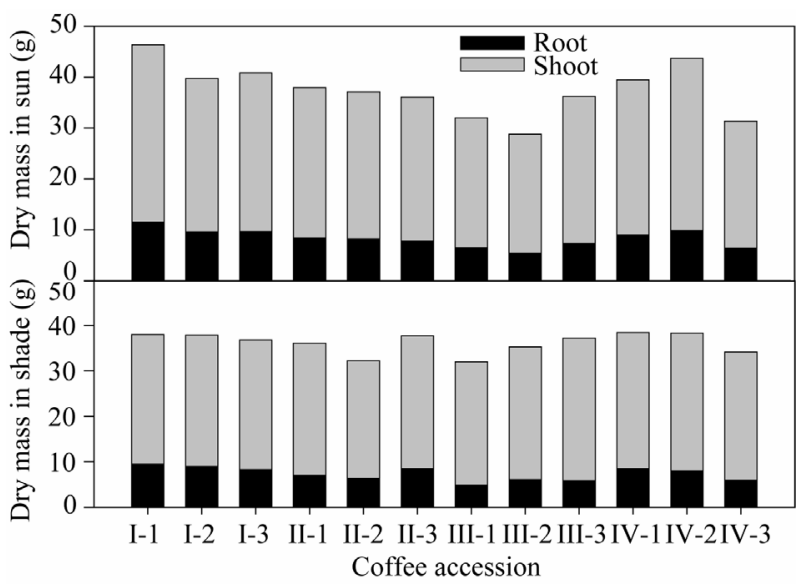

Figure 2. Root and shoot dry mass for seedlings of wild coffee accessions under (a) full sunlight and (b) shaded conditions.

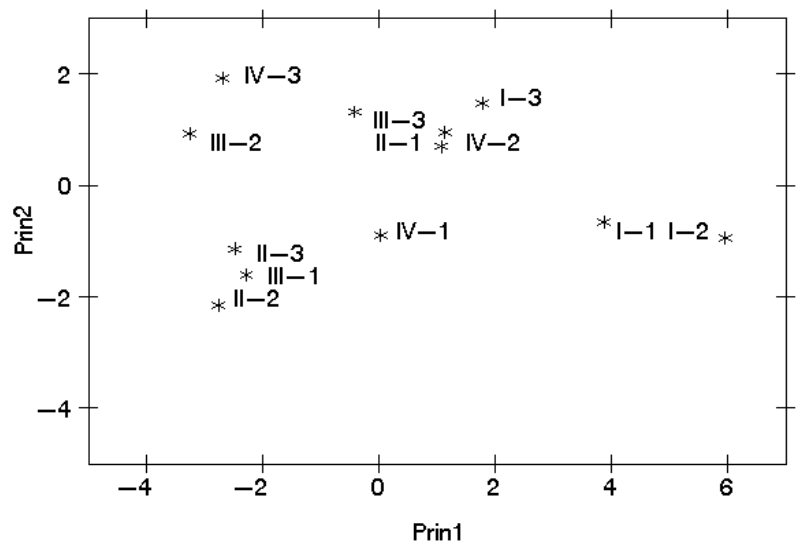

Figure 3. Principal component analysis for destructive growth parameters of coffee seedlings maintained under optimal environmental conditions.

to $35.89 \% \pm 2.92 \%$ and $34.63 \% \pm 2.50 \%$ to $35.37 \% \pm$ $2.90 \%$ between full sun and shade and drought-stressed and irrigated seedlings, respectively. Furthermore, in full sunlight, the stem plus branch part shared significantly ( $\mathrm{P}$ $<0.05)$ more of the total assimilates $(43.67 \% \pm 1.55 \%)$ as opposed to seedlings in partial shade conditions (Table 3$)$.

The total dry matter yield distributed to leaf and total shoot part was, however, not altered due to irrigation regimes. Hence, the average leaf and shoot shares ranged between $43.03 \% \pm 1.75 \%$ and $43.30 \% \pm 1.53 \%$ and $77.66 \% \pm 2.02 \%$ and $78.67 \% \pm 2.68 \%$, respectively. This was similar to the slightly higher assimilate amounts $(78.55 \% \pm 2.81 \%)$ stored in the shoot part of shaded seedlings, though the allocation to the root part was low (Table 3). This corresponds with the more luxurious shoot growth of coffee seedlings at resource rich environments as opposed to deep root systems in droughtstressed situations. The coffee accessions from BerhaneKontir had significantly $(\mathrm{P}<0.01)$ the lowest $(18.3 \%)$ 
Table 3. Total dry matter partitioning patterns (means \pm SD) in seedlings of Arabica coffee genotypes under varying nursery environments.

\begin{tabular}{|c|c|c|c|c|}
\hline Treatment & Root & Leaf & Stem & Whole-shoot \\
\hline Irradiance & Ns & $* * *$ & $*$ & Ns \\
\hline Open sun & $22.22 \pm 1.89$ & $34.11 \pm 2.19 b$ & $43.67 \pm 1.55 a$ & $77.78 \pm 1.90$ \\
\hline Moderate shade & $21.45 \pm 2.81$ & $35.89 \pm 2.92 \mathrm{a}$ & $42.66 \pm 1.58 b$ & $78.55 \pm 2.81$ \\
\hline Irrigation & Ns & * & Ns & Ns \\
\hline Water stressed & $22.35 \pm 2.02$ & $34.63 \pm 2.50 \mathrm{~b}$ & $43.03 \pm 1.75$ & $77.66 \pm 2.02$ \\
\hline Well-watered & $21.33 \pm 2.68$ & $35.37 \pm 2.90 \mathrm{a}$ & $43.30 \pm 1.53$ & $78.67 \pm 2.68$ \\
\hline Genotype & $* *$ & $* * *$ & Ns & $* *$ \\
\hline I-1 & $23.68 \pm 1.89 a b$ & $31.33 \pm 1.14 \mathrm{de}$ & $45.00 \pm 1.55$ & $76.33 \pm 1.89 b c$ \\
\hline $\mathrm{I}-2$ & $24.82 \pm 0.87 a$ & $31.21 \pm 1.61 \mathrm{e}$ & $43.98 \pm 1.19$ & $75.18 \pm 0.87 c$ \\
\hline $\mathrm{I}-3$ & $23.33 \pm 0.66 \mathrm{ab}$ & $34.62 \pm 0.99 b c$ & $42.05 \pm 0.73$ & $76.67 \pm 0.66 b c$ \\
\hline II-1 & $21.48 \pm 1.19 a b c$ & $35.38 \pm 0.92 b c$ & $43.15 \pm 1.05$ & $78.53 \pm 1.19 a b c$ \\
\hline II-2 & $22.16 \pm 1.45 \mathrm{abc}$ & $34.52 \pm 1.50 \mathrm{c}$ & $43.32 \pm 1.48$ & $77.84 \pm 1.44 \mathrm{abc}$ \\
\hline II-3 & $22.37 \pm 2.04 \mathrm{abc}$ & $35.51 \pm 3.48 \mathrm{abc}$ & $42.13 \pm 2.20$ & $77.64 \pm 2.04 a b c$ \\
\hline III-1 & $19.50 \pm 3.15 b c$ & $35.87 \pm 1.09 \mathrm{abc}$ & $44.64 \pm 2.90$ & $80.50 \pm 3.15 a b$ \\
\hline III-2 & $20.75 \pm 2.89 a b c$ & $37.71 \pm 3.00 \mathrm{ab}$ & $41.54 \pm 0.57$ & $79.25 \pm 2.89 a b c$ \\
\hline III-3 & $18.34 \pm 1.86 \mathrm{c}$ & $38.62 \pm 2.52 \mathrm{a}$ & $43.05 \pm 1.16$ & $81.66 \pm 1.85 a$ \\
\hline IV-1 & $21.88 \pm 1.32 \mathrm{abc}$ & $34.94 \pm 1.00 \mathrm{bc}$ & $43.18 \pm 1.73$ & $78.13 \pm 1.33 \mathrm{abc}$ \\
\hline IV-2 & $22.39 \pm 0.92 \mathrm{abc}$ & $34.47 \pm 1.07 \mathrm{~cd}$ & $43.15 \pm 0.76$ & $77.62 \pm 0.93 \mathrm{abc}$ \\
\hline IV-3 & $21.38 \pm 2.81 \mathrm{abc}$ & $35.81 \pm 2.85 \mathrm{abc}$ & $42.82 \pm 0.74$ & $78.62 \pm 2.81 \mathrm{abc}$ \\
\hline Mean & 21.84 & 35.00 & 43.17 & 78.16 \\
\hline CV (\%) & 7.67 & 3.18 & 3.30 & 2.14 \\
\hline
\end{tabular}

Ns $=$ Not significant; ${ }^{*},{ }^{* *}$ and ${ }^{* * *}=$ significant at $\mathrm{P}<0.05, \mathrm{P}<0.01$ and $\mathrm{P}<0.001$, respectively. Means followed by the same letter(s) with in a column are not different from each other (Tukey test at $\mathrm{P}=0.05$ ).

root partitioning as compared to the Harenna seedlings, which had the highest (38.6\%) root share. The results indicate significant differences among accessions in the patterns of total biomass partitioned in leaf $(\mathrm{P}<0.001)$ and shoot $(\mathrm{P}<0.01)$ growth organs. Consequently, the values ranged between $31.2 \%$ and $38.6 \%$ for leaves and between $75.2 \%$ and $81.7 \%$ for the shoot. Under ideal shade and irrigation regimes, differences among accessions in the allocation of total biomass were not significant. However, low leaf partitioning was observed in the Harenna accessions as compared to those from the Bonga and Berhane-Kontir forests. Maximum leaf portioning was also observed in one of the accessions from the Yayu populations (IV-3 = 35.8\%). On the other hand, stem plus branch partitioning was comparable among coffee genotypes, with the values ranging between 41.5 and $44.6 \%$ for III-2 and III-3 of the Berhane-Kontir accessions, respectively (Table 3, Figure 4).

\section{DISCUSSION}

\subsection{Biomass Assimilation}

The results show significantly higher shoot dry mass

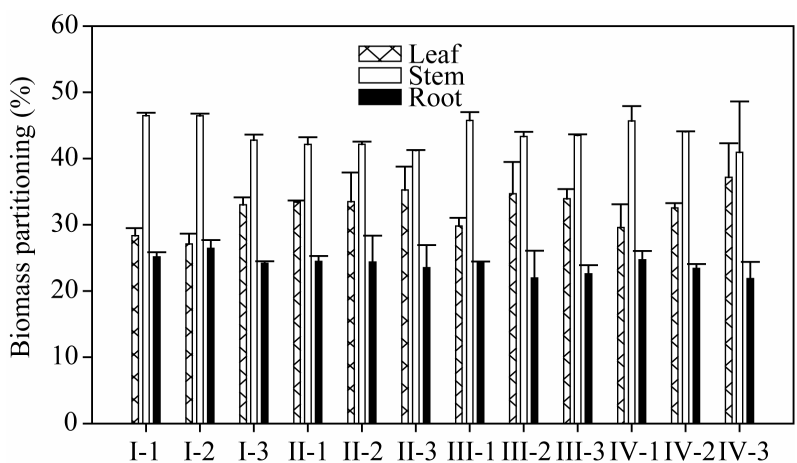

Figure 4. Total dry matter partitioning to root and shoot parts in seedlings of Arabica coffee germplasm accessions.

production in unshaded and progressively droughted coffee seedlings. This could in part be related to low stomatal conductance and concomitantly lower rate of net carbon assimilation in shade and irrigated plants compared to short-term drought-stressed plants [15]. Moreover, a reduced leaf growth was noted in shade compared to sun plots, and such smaller leaf area may alter assimilate partitioning among the tree organs and 
decrease shoot dry matter yield, in part indicating the effect of micro-climatic variables at coffee nurseries (Table 1). This suggests that a major mode of adjustment to reduced soil water demand by the coffee seedlings, at least in the early stages of soil moisture deficit irrigation, could consist of the maintenance of nearly constant assimilation on an area basis through a reduction in the rate of increase in average leaf size. This indicates that leaf expansion can be accompanied by growth and development as well as accumulation and synthesis of the leaf cell components. Similar results were also reported for field-grown robusta coffee [16].

On the other hand, coffee accessions significantly differed in stem dry weight with the lowest and highest average results obtained from the Berhane-Kontir and Harenna seedlings, respectively. This could reflect the variations among the coffee genotypes in growth rate and productivity, which in turn depend upon stem nature (stiff or flexible) and size of water conducting tissue [17]. The results of dry matter production and partitioning are in line with the maximum hydraulic conductance measured in full sun light and irrigated seedlings [12]. Moreover, other finding [18] also indicated the enhanced water use of the arabica coffee populations with a decreased rainfall gradient in Ethiopia. This could be associated, among others, with the specific growth responses including increased number of lateral roots, higher root to shoot ratio as well as decreased leaf-specific area in drought-stressed coffee seedlings [19].

In this regard, many other authors [20-22] pointed out that plants withstand drought stress by drought tolerance (higher biomass allocation to vegetative organs and root to shoot ratio), whereas drought escape strategies involve early flower set and leaf senescence. According to the work done [16], water deficit led to marked decreases in net carbon assimilation rate and to a lesser extent in stomatal conductance, regardless of the low and high nitrogen levels. In Ethiopia, variations among coffee varieties were found [23] due to soil moisture deficit irrigation and their capacity to establish in more stressful field conditions. This concurs with the previous findings [13] that underlined similar patterns of total dry matter production and allocation in Arabica coffee seedlings due to varied potting media blends. The response of the coffee seedlings could also suggest a drought-stress resistance strategy investing more of the daily biomass production in the root system, while penalizing the shoot system. This may be explained due to the differences in root and shoot growth habits and thus hydraulic conductance in coffee seedlings as elucidated [19].

\subsection{Biomass Partitioning}

The amount of total dry mass partitioned to the root part was comparable between the shade and irrigations regimes, though the results were higher for partially shaded and well-irrigated seedlings. By contrast, the coffee accessions significantly $(\mathrm{P}<0.001)$ differ in total biomass share to root, leaf and whole shoot part. For maximum rate of production of dry matter within the plant as a whole it is important that a high proportion of assimilates as possible should be returned to the leaf tissue, which will further increase the productive capacity of the plant, and that expenditure of dry matter on the rest of the plant (stems, petioles and roots) should be no more than is required to efficiently support the leaves and supply sufficient mineral nutrients and water. The overall rate of utilization of assimilates in leaf production depend upon the rate of new leaf initiation, the rate of growth and final leaf size and the branching habit [24]. Under field conditions, assimilate utilization may be limited by various external factors including temperature, and the supply of water and mineral elements [1]. However, there is evidently some homeostatic mechanism maintaining a given root-shoot balance under any given set of conditions, and this in turn implies an interplay between growth in root and shoot components [25]. Changes in the partitioning of dry matter between roots and shoots brought about by environmental factors suggest that when the size of the source is reduced, the growth of organs most remote from it is often particularly affected [26]. Similarly, assimilate allocation in plants was found to be affected by water deficit stress conditions [15]. Hence, the manner in which dry matter is partitioned between the different parts of the plant is clearly of great importance both in natural vegetation and in crop plants.

In essence, the growth and seed production is a result of the integrated processes of photosynthetic carbon dioxide assimilation and subsequent partitioning and utilization of the assimilated carbon. This requires efficient translocation of photo-assimilates to the developing plant parts $[8,9]$. A method of studying energy allocation in plants that requires separating individual plants into component tissues has been reported [27] according to their function, and expressing energy allocation as a proportion of total biomass stored in each tissue type. There are several reasons why weight is used to measure biomass allocation patterns. According to available information $[8,20]$, energy content and dry weight equally reflect energy allocation pattern and dry weight is reported to reflect the integration of all physiological processes throughout the growing season. In addition, dry weight reflects the functional aspects of all assimilation [28].

In many crop species, increased yields of improved cultivars have been related to changes in partitioning as opposed to increase in total biomass [29]. In the tall, 
mature field-grown Arabica coffee trees in Kenya, shoot growth is reported to be associated with seasonal changes in dry matter distribution within the [7]. Green-housegrown Arabica coffee cultivar-Ruiru 11 showed that dry matter partitioning to above- and below-ground parts varied with accessions [27]. The present finding could be explained in terms of the variations in morphological growth natures in seedlings of the same coffee populations [30]. This corroborates with the previous results [13] on the influence of potting media on dry matter yield and allocation in coffee seedlings. Cognizant of the importance of coffee, its high genetic erosion in the centers of origin and minimal conservation efforts emphasized the need for immediate conservation meas- ures to safeguard the sustainability of the global coffee industry [10].

\section{CONCLUSION}

The study depicted that biomass production and distribution patterns in coffee seedlings varied due to genotypes and environmental modifications, singly and/or in combinations. The present findings provide an insight research information to evaluate and characterize growth response of coffee germ plasm accessions to the induced heat and water stress environments. This contributes to identify and develop drought tolerant arabica coffee cultivars against the expansion of coffee cultivation to open sun fields and marginal sites coupled with changing climatic variables. It can be concluded that dry matter production and partitioning patterns in the various growth organs of coffee seedlings can be considered and used as selection criteria in future breeding program. This would also demonstrate the variability among the Ethiopian coffee diversity in biomass assimilation and allocation and the need to maintain optimum nursery environments for production of high quality coffee seedlings. However, better understanding on underlying adaptation mechannisms involved in coffee genetic divesities calls for detail ecophysiologcal and breeding works under specific ecological zones, prodution systems and field management practices for sustainable use and preservation of arabica coffee genetic resources and its ideal environments in Ethiopia.

\section{ACKNOWLEDGEMENTS}

The author would like to appreciate the financial support from the German Federal Ministry for Education and Research (BMBF) and the Ethiopian Institute of Agricultural Research (EIAR). My deepest thanks also go to Alemseged Yilma for his versatile and untiring technical supports to the success of the study.

\section{REFERENCES}

[1] Wintgens, J.N. (2004) Coffee: Growing, processing, sus- tainable production. A guide for growers, traders, and researchers. WILEY-VCH Verlag GmbH and Co. KGaA, Weinheim.

[2] Chaves, R.M., Ten-Caten, A., Pinheiro, H.A., Ribeiro, A. and Damatta, F.M. (2008) Seasonal changes in photoprotective mechanisms of leaves from shaded and unshaded field-grown coffee (Coffea arabica L.) trees. Trees, 22, 351-361. doi:10.1007/s00468-007-0190-7

[3] Beer, J., Muschler, R.G., Kass, D. and Somarriba, E. (1998) Shade management in coffee and cacao plantations. Agroforestry Systems, 38, 139-164. doi:10.1023/A:1005956528316

[4] DaMatta, F.M. (2004) Ecophysiological constraints on the production of shaded and unshaded coffee: A review. Field Crops Research, 86, 99-114.

doi:10.1016/j.fcr.2003.09.001

[5] Franck, N., Vaast, P., Génard, M. and Dauzat, J. (2006) Soluble sugars mediate sink feedback down-regulation of leaf photosynthesis in field-grown Coffea arabica. Tree Physiology, 26, 517-525. doi:10.1093/treephys/26.4.517

[6] Wrigley, G. (1988) Coffee. Tropical Agriculture Series, John Wiley and Sons, Inc., London, New York.

[7] Cannell, M.G.R. (1971) Production and distribution of dry matter in trees of Coffea arabica L. in Kenya as affected by seasonal climatic differences and the presence of fruits. Annals of Applied Biology, 67, 99-120. doi:10.1111/j.1744-7348.1971.tb02910.x

[8] Devlin, R.M. and Witham, F.G. (1983) Plant physiology. 4th Edition, CBS, New Delhi.

[9] Hale, M.G. and Orcutt, D.M. (1987) The physiology of plant under stress. John Wiley and Sons, Inc., New York.

[10] Bellachew, B. and Sacko, J.C. (2009) Coffee genetic resources under severe threat from genetic erosion in the centres of origin and diversity: An urgent need for conservation measures. Proceedings of the 22nd International Conference on Coffee Science, Campinas, 14-19 September 2008, 1487-1496.

[11] Taye, K. (2010) Environmental sustainability and coffee diversity in Africa. International Coffee Organization World Coffee Conference, Guatemala City, 26-28 February 2010.

http://dev.ico.org/event_pdfs/wcc2010/presentions//wcc2 010-kufa.pdf.

[12] Taye, K. (2006) Ecophysiological diversity of wild Arabica populations in Ethiopia: Growth, water relations and hydraulic characteristics along a climatic gradient. Ph.D. thesis, Ecology and Development Series, No. 46, $\mathrm{Cu}-$ villier Verlag, Gottingen.

[13] Taye, K., Mesfin, A. and Paulos, D. (2004) Dry matter production and distribution in Arabica coffee seedlings as affected by media components. In: Asfaw, Z., Getachew, B., Belay, S., Bulcha, W. and Nigussie, A., Eds., Proceedings of the Tenth Crop Science Society of Ethiopia, SEBIL, 10, 154-164.

[14] Institute of Agricultural Research (IAR) (1996) Recommended Production Technologies for Coffee and Associated Crops. IAR, Jimma Agricultural Research Center, Addis Ababa, 17. 
[15] Setter, T.L. (1992) Assimilate allocation in response to water deficit stress. International Crop Science of America, Inc., Madson.

[16] DaMatta, F.M., Loos, R.A., Silva, E.A. and Loureiro, M.E. (2002) Limitations to photosynthesis in Coffea canephora as a result of nitrogen and water availability. Journal of Plant Physiology, 9, 975-981. doi:10.1078/0176-1617-00807

[17] Yacob, E., Tesfaye, S., Taye, K., Alemseged, Y., Takele, N., Anteneh, N. and Bekele, B. (1996) Advances in coffee agronomy research in Ethiopia. In: Tenywa, J.S., Adipala Ekwamu and M.W. Ogengalatogo, Eds., Proceedings of Inter-Africa Coffee Organization Workshop, 4-6 September 1995, Kampala, 40-45.

[18] Burkhardt, J., Kufa, T, Beining, A, Goldbach, H. and Fetene, M. (2007) Different drought adaptation strategies of Coffea arabica populations along rainfall gradient in Ethiopia. Proceedings of the 21st International Conference on Coffee Science Colloquium, 11-15 September 2006, Montpellier, France, 1032-1036.

[19] Taye, K. and Burkhardt, J. (2008) Ecophysiology of wild Coffea arabica populations in the montane rainforests of Ethiopia. Proceedings of a National Workshop, Four Decades of Coffee Research and Development in Ethiopia, 14-17 August 2007, Addis Ababa (Ghion Hotel), 140149.

[20] Salisbury, F.B. and Ross, C. (1992) Plant physiology. Wadsworth Publishing Company, Belmont.

[21] Prasad, M.N.V. (1997) Plant ecophysiology. John Wiley \& Sons, Inc., New York.

[22] Larcher, W. (2003) Physiological plant ecology: Eco- physiology and stress physiology of functional groups. 4th Edition, Springer-Verlag, Berlin.

[23] Tesfaye, S. (2006) Growth, water relation, yield and crop quality of Arabica coffee in response to water stress and deficit irrigation. Ph.D. Thesis, University Putra Malaysia, Serdang.

[24] Hopkins, W.G. (1995) Introduction to plant physiology. John Wiley and Sons, Inc., New York.

[25] Wareing, P.F. (1970) Growth and its coordination in trees. In: Luckmill, L.C. and Cutting, C.W., Eds., Physiology of tree crops. Academic Press, London and New York.

[26] Russel, R.S. (1977) The plant root systems: Their function and interaction with the soil. MC Graw-Hill Book Company (UK) Limited Maidenhead, Berkshire.

[27] Gathaara, M.P.H., Muthur, F.M. and Cheruiyot, R.C. (1997) Biomass accumulation in the various plant organs of coffee Arabica L., cultivar Ruiru 11, under drip irrigation in Kenya. ASIC 17th Colloquium, Nairobi, 752-759.

[28] Pandey, S.N. and Sinha, B.K. (1996) Plant physiology. 3rd Revised Edition, Vikas Publishing House PVT Ltd., New Delhi.

[29] Egli, D.B. (1988) Alternation in plant growth and dry matter distribution in soybean. Agronomy Journal, 80, 86-90. doi:10.2134/agronj1988.00021962008000010020x

[30] Kufa, T. and Burkhardt, J. (2009) Morpho-agronomic characterization of seedlings of wild Coffea arabica accessions under controlled conditions in southwestern Ethiopia. Proceedings of the 22nd International Conference on Coffee Science, 14-19 September 2008, Campinas, 1552-1562. 